REPORTS OF MORPHOLOGY
$\begin{gathered}\text { Official Journal of the Scientific Society of Anatomists, } \\ \text { Histologists, Embryologists and Topographic Anatomists } \\ \text { of Ukraine } \\ \text { journal homepage: https://morphology-journal.com }\end{gathered}$

\title{
Features of microscopic changes in lung structure of young rats under conditions of hyperhomocysteinemia
}

Samborska I.A.

National Pirogov Memorial Medical University, Vinnytsya, Ukraine

\section{ARTICLE INFO}

Received: 31 May, 2019

Accepted: 23 June, 2019

UDC: $616.24: 577.112 .386: 599.323 .45$

\section{CORRESPONDING AUTHOR}

e-mail: samborska1990@gmail.com Samborska I.A.

\begin{abstract}
Hyperhomocysteinemia is a risk factor for many diseases, including pathologies of the respiratory system. The pathogenesis of lung tissue damage is complex and multifactorial, however, it has now been found that homocysteine has a toxic effect on the vascular system and parenchyma of the organ. The purpose of the study is to identify the features of microscopic changes in the structure of the lungs of young rats under conditions of hyperhomocysteinemia. The experimental study was performed on 22 white non-linear young (1-2 months) male rats. During the experiment, the animals were divided into two groups - control and experimental. Simulation of persistent hyperhomocysteinemia was achieved by administering to rats of the experimental group thiolactone homocysteine at a dose of $200 \mathrm{mg} / \mathrm{kg}$ body weight intragastrically for 60 days. Histological specimens were examined using an SEO SCAN light microscope and photo-documented using a Vision CCD Camera with the system output images of histological preparations. It was found that the introduction of thiolactone homocysteine to young rats at a dose of $200 \mathrm{mg} / \mathrm{kg}$ led to the development of destructive changes in blood vessels, bronchi, components of the respiratory department with signs of atelectasis. Hemodynamic disorders and increased vascular permeability led to perivascular, peribronchial, interstitial, intra-alveolar edema, histo-leukocyte infiltration. The detected changes are reversible and have a compensatory nature.
\end{abstract}

Keywords: hyperhomocysteinemia, lungs, aerohematic barrier, macrophages, neutrophils.

\section{Introduction}

Homocysteine $(\mathrm{HC})$ is a non-proteinogenic amino acid that is formed in the body under normal conditions during methionine metabolism. A considerable amount of it is involved in methionine resynthesis by transsulfuration [7]. Also, recycling of $\mathrm{HC}$ is carried out through remethylation and desulfurization reactions. Vitamins B6, B9 and B12 have been found to be extremely important for its metabolism, since they are involved in the synthesis of coenzymes, without which the metabolism of this amino acid is impossible [20]. According to most researchers, the normal level of $\mathrm{HC}$ in the blood is 5-15 $\mu \mathrm{mol} / \mathrm{L}$ [22]. However, due to impaired synthesis and recycling processes, its level may increase, leading to the development of a health-threatening condition of hyperhomocysteinemia. To date, many causes for the development of hyperhomocysteinemia have been proven. These include: hereditary defects of enzymes methylenetetrahydrofolate reductase, cystathionine- $\beta$ synthase, methionine synthase; taking certain medicines (oral contraceptives, barbiturates, etc.), a diet high in methionine, kidney disease, drinking lots of coffee, smoking, alcoholism, a sedentary lifestyle [11, 13, 21]. Careful analysis of the sources of scientific literature has established that hyperhomocysteinemia is an independent risk factor for the development of coronary heart disease, strokes, obliterating atherosclerosis of the lower extremities, arterial and venous thrombosis, chronic heart failure [3, 4]. Numerous studies have also demonstrated its relationship to Alzheimer's disease, autism, vascular dementia, pregnancy miscarriage, non-alcoholic fatty liver disease, osteoporosis, cancer [9, 16].

In recent years, studies have focused on the relationship between blood plasma $\mathrm{HC}$ and the onset and progression of lung disease. Patients with chronic obstructive pulmonary disease record a state of hyperhomocysteinemia, which, according to the researchers, is evidence of severe disease [15]. Hypotheses regarding the role of $\mathrm{HC}$ in lung and pleural cancer development are also available [5]. 
$\mathrm{HC}$ has a direct toxic effect on the endothelial layer of the vascular wall, so in the pathogenesis of lung lesions in hyperhomocysteinemia attach great importance to the vascular system of the organ. In particular, it has been proved that $\mathrm{HC}$ causes a violation of the reactivity of the pulmonary artery wall due to the development of oxidative stress [18]. In addition, the $\mathrm{HC}$ is able to exert a direct damaging effect on the lung parenchyma and extracellular matrix [17].

Thus, studying the peculiarities of morphological changes in the structure of the lungs is an extremely important task, since the data obtained will contribute to a better understanding of the key links in the pathogenesis of hyperhomocysteinemia, to improve the diagnosis and treatment of respiratory diseases.

The purpose of the study is to identify the features of microscopic changes in the structure of the lungs of young rats under conditions of hyperhomocysteinemia.

\section{Materials and methods}

The experiments were performed on 22 white nonlinear young (1-2 months) male rats. During the experiment, the animals were divided into two groups - control and experimental. Simulation of persistent hyperhomocysteinemia was achieved by administering rats of the thiolactone $\mathrm{HC}$ to rats of test group at a dose of $200 \mathrm{mg} / \mathrm{kg}$ body weight intragastrically for 60 days. Animals were immobilized by decapitation under thiopental anesthesia. For microscopic examination, pieces of lung were collected from pre-weighed animals of all groups. The pieces were fixed in $10 \%$ formalin solution, the duration of the exposure did not exceed 1-2 days. The fixing solution used prevents the autolysis process and stabilizes the cells and tissues for their further processing and use in staining procedures. Next, the dehydration of the pieces in alcohols of increasing concentration and poured into paraffin blocks. The sections, 4-5 $\mu \mathrm{m}$ thick, were stained with hematoxylin and eosin and methylene blue [6]. Histological specimens were examined using an SEO SCAN light microscope and photo-documented using a Vision CCD Camera with the system of output of the image from histological preparations.

\section{Results}

Histological studies of the lungs of young rats under conditions of hyperhomocysteinemia caused by the introduction of thiolactone $\mathrm{HC}$ at a dose of $200 \mathrm{mg} / \mathrm{kg}$, revealed impaired pulmonary hemodynamics, edema of the structural components of the respiratory compartment, vessel walls and bronchi.

Large, medium and especially small bronchial tubes and bronchioles are characterized by swelling and thickening of the wall, its deformation. Destruction of the fibro-cartilage sheath and muscle plate resulted in a reduction of the mucous folds. In the lumen of the bronchi revealed serous mucous contents with desquamated epitheliocytes. Adventitia infiltrated with leukocytes,

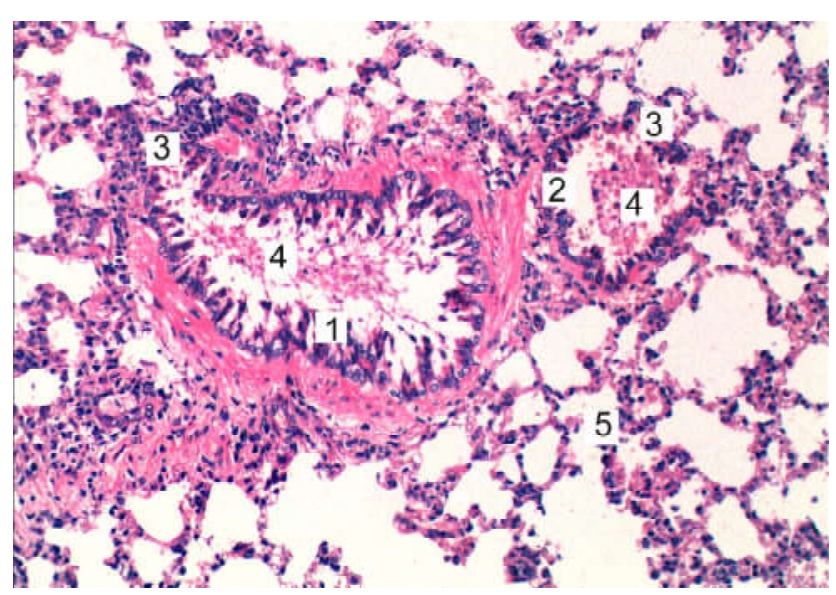

Fig. 1. Microscopic changes in the lungs of young rats under conditions of hyperhomocysteinemia. Large (1) and medium diameter (2) bronchus, deformation of the wall (3), serous-mucous contents in the lumen (4), respiratory department (5). Staining with hematoxylin and eosin. x100.

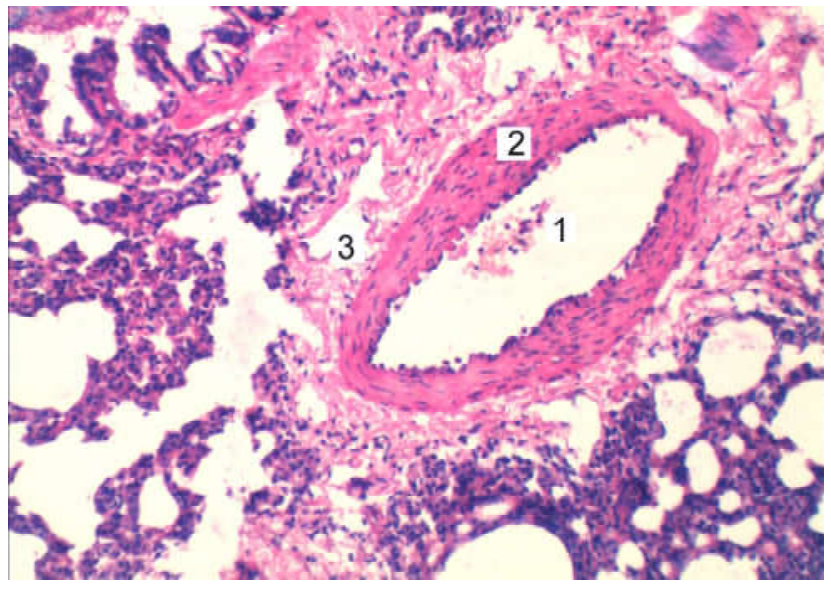

Fig. 2. Histological changes in the lungs of young rats under conditions of hyperhomocysteinemia. Large-diameter artery lumen (1), edema, media (2) and adventitia (3) destruction. Staining with hematoxylin and eosin. x100.

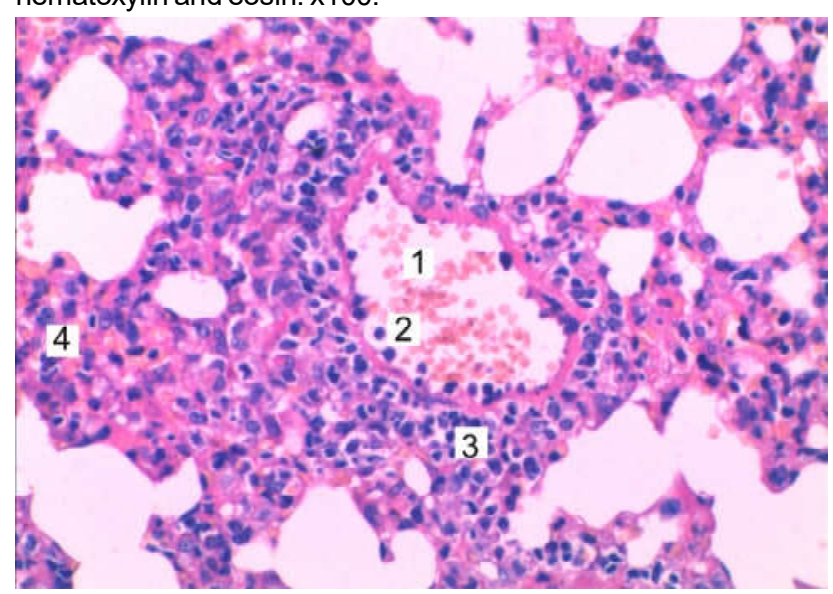

Fig. 3. Microscopic changes in the lungs of young rats under conditions of hyperhomocysteinemia. Small-diameter vein lumen (1), marginal lymphocyte standing near endothelium (2), leukocyte accumulation in adventitia (3), swelling and infiltration of respiratory compartment (4). Staining with hematoxylin and eosin. x200. 


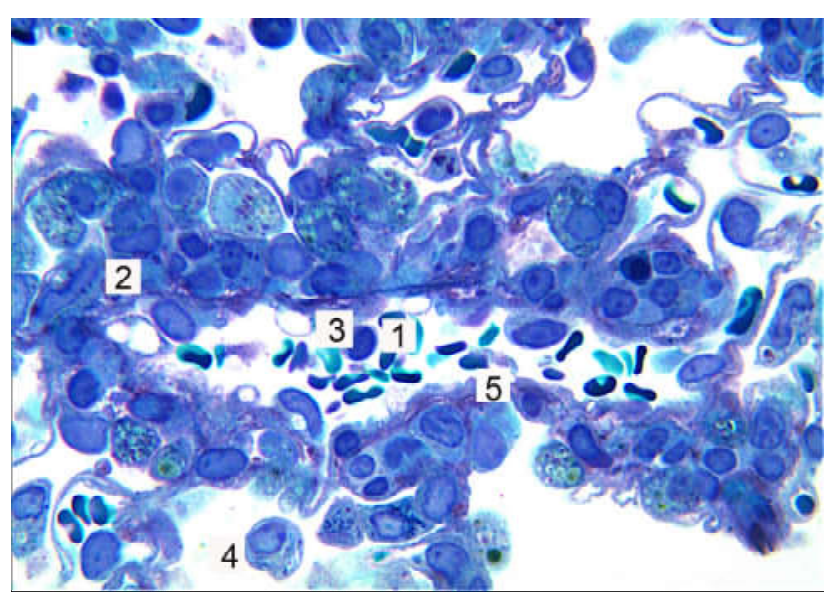

Fig. 4. Microscopic changes in the lungs of young rats under conditions of hyperhomocysteinemia. Venula lumen with blood cells (1), histoleukocyte infiltration of the wall (2), destructively altered endothelial cells (3), alveolar macrophages in the lumen of the alveoli (4), basement membrane (5). Semi-thin section. Methylene blue. x400.

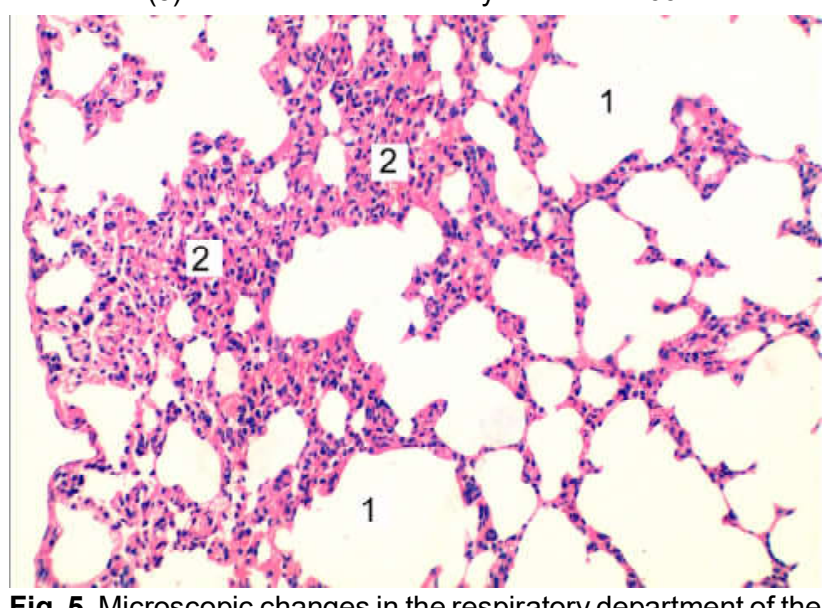

Fig. 5. Microscopic changes in the respiratory department of the lungs of young rats under conditions of hyperhomocysteinemia. Alveolar sacs (1), sites of atelectasis and histo-leukocyte infiltration (2). Staining with hematoxylin and eosin. x100.

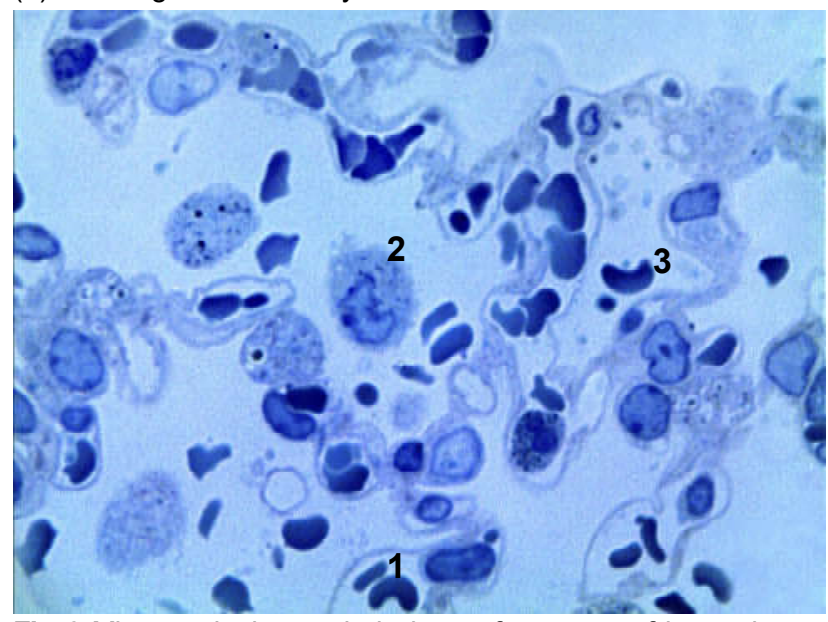

Fig. 6. Microscopic changes in the lungs of young rats of the respiratory department under conditions of hyperhomocysteinemia. Blood filled capillaries (1), alveolar macrophages (2), erythrocytes in the lumen of the alveoli (3). Semi-thin section. Methylene blue. x400. macrophages (Fig. 1).

Reorganization of the vascular wall of large and medium diameter manifested expansion gaps and blood flow, edema and leukocyte infiltration, predominantly adventitia, also revealed blood vessels with narrowed lumen (Fig. 2, Fig. 3).

Microscopic changes in the vessels of the microcirculatory bed on semi-thin sections were characterized by heteromorphism. The venous blood flow was determined, with stasis, erythrocyte coagulation, platelet accumulation, neutrophils in the lumen, and leukocyte marginal standing near the endothelium. In the swollen endothelial cells, vacuoles were found, burning the nuclei into the lumen of the vessel. The basement membrane was also swollen, indistinct (Fig. 4). Microvessels with thickened wall, cramped by a narrow lumen were also detected. Dystonia of the vessel wall was also manifested by thinness, uneven thickening, narrow or collapsed lumen.

Manifestations of inflammatory character were determined in the migration of leukocytes mainly of lymphocytes into the intra alveolar septa with the formation of foci of inflammation.

In the respiratory department of the lungs, the intra alveolar septa were thickened due to the blood filling of the hemocapillaries and edema due to the increased permeability of the walls of the microvessels to the blood plasma. Histo-leukocyte infiltration of the parenchyma of the organ was also detected. The gaps of the alveoli showed an increase in the number of alveolar macrophages.

Among the unchanged histostructure of the lung tissue, small areas of dys- and atelectasis were also identified, with partially or completely absent luminal alveoli (Fig. 5). In the peripheral, subpleural areas, an emphysematous altered lung tissue was observed with sophisticated intra alveolar septa and significantly enlarged gups of the alveoli. The thinned sections of the aerohematic barrier were destroyed or ruptured, which led to the formation of elements and plasma in the lumen of the alveoli (Fig. 6).

\section{Discussion}

The data obtained from the experimental study confirm the already existing results, conducted with the aim of establishing the role of $\mathrm{HC}$ in lung injury. In particular, it was found that hyperhomocysteinemia, which develops as a result of cystathionine- $\beta$-synthase deficiency, leads to the development of pulmonary artery thrombosis, characterized by the presence of pulmonary tissue fibrosis and the destruction of the aerohematic barrier. The changes are accompanied by increased expression of collagen type I and transforming growth factor- $\beta 1$ [8].

Severe chronic hyperhomocysteinemia causes activation of lipid peroxidation and inhibition of mechanisms of antioxidant protection of the lungs. The result of these changes is the development of oxidative stress, which 
causes damage to lung tissue, increased production of macrophages and lymphocytes [2].

It has been established that in severe hyperhomocysteinemia, $\mathrm{HC}$ accumulates in the mitochondria of the lungs in rats, causing a direct toxic effect on them. Under these conditions, the metabolism of NO is impaired and its bioavailability is reduced, however, the production of reactive oxygen species is enhanced against the background of inhibition of the reserve-adaptive potential of lung mitochondria and, as a consequence, damage to the organ parenchyma [12].

To date, the role of hyperhomocysteinemia in the development of endothelial dysfunction has been confirmed. The latter is due to increased production of reactive oxygen species and reduced synthesis of nitric oxide. The decrease in the level of nitric oxide under conditions of hyperhomocysteinemia can also be caused by inhibition of the enzyme dimethylarginine dimethylaminohydrolase. Hyperhomocysteinemia-induced damage to mitochondrial DNA leads to dysfunction of these organelles and exacerbates bioenergetic processes in them, leading to the appearance of a closed circle and increased signs of oxidative stress. In addition,

\section{References}

[1] Bai, Y., Fang, F., Jiang, J., \& Xu, F. (2017). Extrinsic Calcitonin Gene-Related Peptide Inhibits Hyperoxia-Induced Alveolar Epithelial Type II Cells Apoptosis, Oxidative Stress, and Reactive Oxygen Species (ROS) Production by Enhancing Notch1 and Homocysteine-Induced Endoplasmic Reticulum Protein (HERP) Expression. Med. Sci. Monit., 23, 5774-5782. doi: 10.12659/ MSM.904549

[2] da Cuncha, A. A., Ferreira, A. G., da Cuncha, M. J., Pederzolli, C. D., Becker, D. L., Coelho, J. G. ... Wyse, A. T. (2011). Chronic hyperhomocysteinemia induces oxidative damage in the rat lung. Mol. Cell. Biochem., 358(1-2), 153-160. doi: 10.1007/ s11010-011-0930-2

[3] Dayal, S., Blokhin, I., Erger, R. A., Jensen, M., Arging, E., Stevens, J. W. ... Lentz, S. R. (2014). Protective Vascular and Cardiac Effects of Inducible Nitric Oxide Synthase in Mice with Hyperhomocysteinemia. PLoS One, 9(9): e107734. doi: 10.1371/journal.pone.0107734

[4] Dionisio, N., Jardin, I., Salido, G. M., \& Rosado, J. A. (2010). Homocysteine, Intracellular Signaling and Thrombotic Disorders. Curr. Med. Chem., 17(27), 3109-3119. doi: 10.2174/ 092986710791959783

[5] Durda, K, K?klewski, K, Gupta, S, Szydlowski, M, Baszuk, P, Jaworska-Bieniek, K. ... Jakubowska, A. (2017). Serum folate concentration and the incidence of lung cancer. PLoS One, 12(5): e0177441. doi: 10.1371/journal.pone.0177441

[6] Goralskiy, L. P., Homich, V. T., \& Kononskiy, O. I. (2011). Fundamentals of histological technique and morphofunctional methods of research in normal and pathology. Zhytomyr: Polissya.

[7] Grechanina, O. Ya. (2013). Methionine - an essential amino acid. Clinical genetics and perinatal diagnostics, 1(2), 1935.

[8] Hamelet, J., Maurin, N., Fulchiron, R., Delabar, J. M., \& Janel, N. (2007). Mice lacking cystathionine beta synthase have lung fibrosis and air space enlargement. Exp. Mol. Pathol., 83(2), homocysteine activates the necrotic factor kappa $\beta$ (NF-k $\beta$ ) and the activation of the blood coagulation system, the production of adhesion molecules, cytokines and chemokines [14].

Experimental studies also revealed that hyperhomocysteinemia causes apoptosis of type II alveolocytes due to the development of oxidative stress in them [1, 10]. Hyperhomocysteinemia and folate deficiency are at risk of developing lung cancer due to impaired DNA synthesis and methylation [19].

\section{Conclusions}

The histological studies of the lungs of young rats under conditions of hyperhomocysteinemia revealed the initial destructive changes of the vessels, bronchi, components of the respiratory department. Hemodynamic disorders and increased vascular permeability led to perivascular, peribronchial, interstitial, intra-alveolar edema, histoleukocyte infiltration. In the tissue of the respiratory department, small areas of dys-and atelectasis, emphysematous expansion, were found among the sites of unchanged organ structure. The detected changes are reversible and have a compensatory nature.

249-253. doi: 10.1016/j.yexmp.2007.04.005

[9] Kaur, R., \& Sekhon, B. S. (2013). Hyperhomocysteinemia: an overviews. International journal of comprehensive pharmacy, $5(1), 1-4$.

[10] Liu, W. L., Liu, Z. W., Li, T. S., Wang, C., \& Zhao, B. (2013). Hydrogen sulfide donor regulates alveolar epithelial cell apoptosis in rats with acute lung injury. Clin. Med. J., 126(3), 494-499. PMID: 23422113

[11] Lutsyuk, M. B., Zaichko, N. V., Grigor'eva, G. S., Konahovich, M. A., Artemchuk, M. A., Pentyuk, N. O., \& Postovitenko, K. P. (2013). Hyperhomocysteinemia syndrome: causes, methods of prevention and treatment. Rational pharmacotherapy, 29(4), 55-60.

[12] Medvedev, D. V., Zvyagina, V. I., Uryasev, O. M., Belskih, E. S., Bulatetskiy, S. V., \& Ryabkov, A. N. (2017). Metabolic changes in lung mitochondria in experimental hyperhomocysteinemia in rats. Biomedical Chemistry, 63(3), 248-254. doi: 10.18097/ PBMC20176303248

[13] Pentyuk, O. O., Lutsyuk, M. B., \& Artemchuk, M. A. (2007). Preclinical studies of hyperhomocysteinemic action of potential drugs. K.: SPC MoH Ukraine.

[14] Pushpakunar, S., Kundu, S. \& Sen, U. (2014). Endothelial Dysfunction: The Link Between Homocysteine and Hydrogen Sulfide. Curr. Med. Chem., 21(32), 3662-3672. PMID: 25005183

[15] Prokofeva, T. V., Lipnitskaya, E. A., Kuzmichev, B. Yu., Polunina, O. S., Voronina, L. P., \& Polunina, E. A. (2019). The effect of chronic obstructive pulmonary disease on the level of homocysteinemia and the condition of the coronary vessels in patients with myocardial infarction. Tuberculosis and lung diseases, 10(97), 12-18. doi: https://doi.org/10.21292/20751230-2019-97-10-12-18

[16] Skovierova, H., Vidomanova, E., Mahmood, S., Sopkova, J., Drgova, A., Cervenova, T. ... Lehotsky, J. (2016). The molecular and cellular effect of homocysteine metabolism imbalance on human health. Intern. J. of Molecular Scien., 17, 1-18. doi: 
10.3390/ijms 17101733

[17] Starcher, B., \& Hill, C. H. (2005). Elastin defects in the lungs of avian and murine models of homocysteinemia. Exp. Lung Res., 31(9-10), 873-885. doi: 10.1080/01902140600611629

[18] Tasatargil, A., Sadan, G., \& Karasu, E. (2007). Homocysteineinduced changes in vascular reactivity of guinea-pig pulmonary arteries: role of the oxidative stress and poly (ADP-ribose) polymerase activation. Pulm. Pharmacol. Ther., 20(3), 265272. doi: 10.1016/j.pupt.2006.02.004

[19] Tastekin, D., Erturk, K., Bozbey, H. U., Olmuscelik, O., Kizitan, H., Tuna, S., \& Tas, F. (2015). Plasma homocysteine, folate and vitamin B12 levels in patients with lung cancer. Exp. Oncol., 37(3), 218-222. PMID: 26422108

[20] Wang, H., Sun, Q., Zhou, Y., Zhang, H., Luo, C., Xu, J. ...Wang,
W. (2017). Nitration-mediated deficiency of cystathione $\beta$ synthase activity accelerates the progression of hyperhomocysteinemia. Free radical biology and medicine, 113, 519-529. doi: https://doi.org/10.1016/ j.freeradbiomed.2017.10.389

[21] Zaichko, N. V. (2010). Homocysteine, cysteine, and hydrogen sulfide levels in blood plasma of patients with deep vein thrombosis: association with C677T polymorphism in methylenetetrahydrofolate reductase gene. Experimental and clinical physiology and biochemistry, (4), 35-41.

[22] Zaichko, N. V., Lutsyuk, M. B., \& Grigor'eva, G. O. (2012). Hyperhomocysteinemia: medico-social and pharmacological aspects. Pharmaceutical courier, (9), 30-35.

\section{ОСОБЛИВОСТІ МІКРОСКОПІЧНИХ ЗМІН СТРУКТУРИ ЛЕГЕНЬ МОЛОДИХ ЩУРІВ ЗА УМОВ ГІПЕРГОМОЦИСТЁ̈НЕМІї Самборська I.A.}

Гіпергомоцистеїнемія є фактором ризику розвитку багатьох захворювань, в тому числі і патології органів дихальної системи. Патогенез ураження тканини легень є складним та багатофакторним, однак на сьогоднішній день встановлено, що гомоцистеїн чинить токсичний вплив на судинну систему та паренхіму органу. Метою дослідження $\epsilon$ виявлення особливостей мікроскопічних змін структури легень молодих щурів за умов гіпергомоцистеїнемії. Експериментальне дослідження проведено на 22 білих нелінійних молодих (1-2 місяці) щурах-самцях. У ході експерименту тварин було розподілено на 2 групи - контрольну і дослідну. Моделювання стану стійкої гіпергомоцистеїнемії досягали шляхом введення щурам дослідної групи тіолактону гомоцистеїну у дозі 200 мг/ке маси тіла інтрагастрально протягом 60 днів. Гістологічні препарати вивчали за допомогою світлового мікроскопа SEO SCAN та фотодокументували за допомогою відеокамери Vision CCD Camera з системою виводу зображення з гістологічних препаратів. Було встановлено, що введення тіолактону гомоцистеїну молодим шурам в дозі 200 мг/ке призвело до розвитку деструктивних змін судин, бронхів, компонентів респіраторного відділу з ознаками ателектазів. Гемодинамічні розлади і посилення судинної проникності призвели до периваскулярного, перибронхіального, інтерстиційного, внутрішньоальвеолярного набряку, гістолейкоцитарної інфрільтрації. Виявлені зміни зворотні та мають пристосувально-компенсаторний характер.

Ключові слова: гіпергомоцистеїнемія, легені, аерогематичний бар'єр, макрофраги, нейтрофріли.

\section{ОСОБЕННОСТИ МИКРОСКОПИЧЕСКИХ ИЗМЕНЕНИЙ СТРУКТУРЫ ЛЕГКИХ МОЛОДЫХ КРЫС В УСЛОВИЯХ ГИПЕРГОМОЦИСТЕИНЕМИИ \\ Самборская И.А.}

Гипергомоцистеинемия является фрактором риска развития многих заболеваний, в том числе и патологии органов дыхательной системы. Патогенез поражения ткани легких является сложным и многофракторным, однако, на сегодняшний день установлено, что гомоцистеин оказывает токсическое воздействие на сосудистую систему и паренхиму органа. Целью исследования является выявление особенностей микроскопических изменений структуры легких молодых крыс в условиях гипергомоцистеинемии. Экспериментальное исследование проведено на 22 белых нелинейных молодых (1-2 месяца) крысах-самцах. В ходе эксперимента животных разделили на две группы - контрольную и опытную. Моделирование состояния устойчивой гипергомоцистеинемии достигали путем введения крысам опытной группы тиолактона гомоцистеина в дозе 200 мг/кг массы тела интрагастрально в течении 60 дней. Гистологические препараты изучали с помощью светового микроскопа SEO SCAN и фоотодокументировали с помощью видеокамеры Vision CCD Camera c cuстемой вывода изображения с гистологических препаратов. Было установлено, что введение тиолактона гомоцистеина молодым крысам в дозе 200 мг/ке привело к развитию деструктивных изменений сосудов, бронхов, компонентов респираторного отдела с признаками ателектазов. Гемодинамические расстройства и усиление сосудистой проницаемости привели к периваскулярному, перибронхиальному, интерстициальному, внутриальвеолярному отеку, гистолейкоцитарной инфильтрации. Выявленные изменения обратимы и имеют приспособительно-компенсаторный характер.

Ключевые слова: гипергомоцистеинемия, легкие, аэрогематический барьер, макрофаги, нейтрофилы. 